\title{
THE FLORENCE NIGHTINGALE/MARY STANLEY CONTROVERSY: SOME UNPUBLISHED LETTERS
}

\author{
by
}

\section{J. O. BAYLEN*}

IN HER brief portrait of Mrs. Catherine Gladstone in 1956, Mrs. Georgina Battiscombe wrote that Mrs. Gladstone's efforts 'to be of some use in the [Crimean] war troubles' brought her into 'a most unfortunate collision' with Florence Nightingale when, under the influence of Mrs. Elizabeth Herbert, Mrs. Gladstone 'threw herself heart and soul ... . into the good work of providing nurses for the military hospitals in Turkey ... . These efforts, declared Mrs. Battiscombe, 'took the form least likely to commend itself to Miss Nightingale ...' because, like Mrs. Herbert, Mrs. Gladstone fell for 'the schemes of Mary Stanley' to lead a second party of nurses to the theatre of war. Mrs. Gladstone assisted Mrs. Herbert and Lady Canning in selecting, outfitting, and dispatching Miss Stanley's group to Constantinople and was soon involved in the quarrels and recriminations which followed the descent of the Stanley party on Turkey, and Florence Nightingale's bitter resentment of this intrusion in her preserve. ${ }^{1}$

Mary Stanley, the third child of Edward Stanley, Bishop of Norwich, and sister of Arthur P. Stanley (1815-81), Dean of Westminster, was a close friend of Florence Nightingale and the Secretary of State for War, Sidney Herbert, and his wife, Elizabeth, since the 1840 s. $^{2}$ An ardent Puseyite, who was converted to the Roman Church during her service in Turkey in 1855, ${ }^{3}$ Mary Stanley shared Florence Nightingale's interest in nursing, but, unlike Florence Nightingale, was an ardent advocate of the Kaiserswerth plan with its emphasis on the instruction of nurses in the art of administering religious comfort to patients ... ${ }^{4}$ She was eight years older than Florence Nightingale, but 'a strange, emotional creature' and an odd blend of religious fervor and jealousy . $\therefore^{5}$ Intensely devoted to Florence Nightingale, Mary Stanley had assisted her in recruiting the first group of nurses to go to Constantinople. She was stirred by the success of the Nightingale experiment and encouraged by Cardinal Manning to lead a second party of predominately Catholic nurses to minister to the needs of Crimean War casualties. ${ }^{6}$ Thus, on learning that Mary Stanley was going to Constantinople, a relative of Mary Stanley wrote: 'So Mary has reached the height of her ambition ... Such nonsense ... to say she did not wish to go.' Persuaded by his wife, Sidney Herbert authorized (without the approval of Florence Nightingale) the dispatch on 2 December 1855, of Mary Stanley and a mixed lot of forty-six women (fifteen nuns, nine ladies, and twenty-two nurses). ${ }^{8}$

When Florence Nightingale learned on 14 December of the impending arrival of the Stanley party, she immediately wrote a vehement remonstrance to Sidney Herbert pointing out that the dispatch of the Stanley group contravened their agreement that

*Regent's Professor of History, Georgia State University, Atlanta, Georgia, U.S.A.

Medical History, 1974, vol. 18. 


\section{Texts and Documents}

no nurses were to be sent to her without her assent. ${ }^{9}$ Her scathing letter to Herbert on 15 December was also prompted by the facts that she had no accommodation for additional nurses, that her only chance of success lay 'in the maintenance of individual responsibility and clearly established authority', and that at the time her authority was being challenged by the chief of the Sellonite nurses and some of the doctors. ${ }^{10}$ Worse yet, the Stanley party was authorized to report only to the Inspector-General of Hospitals, Dr. Alexander Cumming, the Irish nuns in the Stanley group recognized no authority except that of their leader, the strong-willed Mother Frances Bridgeman, who, in turn, was responsible only to her bishop, and Mary Stanley was an outspoken pro-Catholic sectarian. ${ }^{11}$ All of this was most difficult for a lady whose cool and calm demeanour (as Lytton Strachey and Lord Stanmore discerned) concealed a fierce and passionate temperament which sometimes exuded 'a jealous impatience of any rival authority ... ${ }^{12}$ These factors explain why Florence Nightingale received Mary Stanley and her party on 15 December with a cold official reserve and refused to accept their services on the grounds that they had come without her consent. ${ }^{13}$

Since there was no room for the Stanley party at the General Hospital in Scutari and Dr. Cumming refused to assume any responsibility for them, the group remained on board their transport until the British Ambassador, Lord Stratford de Redcliffe, provided temporary quarters for the women in Therapia. As the nurses and ladies fell to bickering, Mary Stanley met with Florence Nightingale on 21 December and requested that twenty of her party be assigned as 'female ecclesiastes' to the hospital chaplains. Miss Nightingale refused and again stated that she had not asked for the party, but offered to lend money from her funds for the subsistence of the group. ${ }^{14}$ While Mary Stanley reported Florence Nightingale's refusal to accept her services to Mrs. Herbert, ${ }^{15}$ Miss Nightingale, seeing that it would be a tactical error to force the return of the Stanley party, relented and on 24 December offered to replace some Catholic Norwood nuns with Mary Stanley's Irish nuns and promised to place some of the new nurses in the convalescent hospital to be opened at Koulali on the condition that Mary Stanley abandon the 'female ecclesiastes' scheme. ${ }^{16}$ But this compromise proved unworkable because the Norwood nuns refused to be relieved and the redoubtable Mother Bridgeman, supported by Mary Stanley, insisted that all of her charges must be assigned to the General Hospital under her authority. ${ }^{17}$ Indeed, in addition to the intransigence of Bridgeman, Florence Nightingale now faced a donnybrook as Protestants and Catholics engaged in recriminations of improper proselytizing to the point where even The Times reported on 9 January 1855, that Florence Nightingale's undertaking was in danger of foundering on the shoals of religious dissension. ${ }^{18}$

In despair, Florence Nightingale offered to abdicate her position to Mary Stanley and, when she refused this responsibility, proposed that Mary Stanley take charge of the General Hospital until she (Miss Nightingale) was superseded. Mary Stanley promised to consider the proposal thinking that she might put one of her ladies, Miss Emily Anderson, in charge of the hospital. Finally, Mary Stanley consented to go to the General Hospital with Emily Anderson and some of her ladies. ${ }^{19}$ A general compromise was arranged towards the end of January 1855, when Florence Nightingale changed the convalescent hospital at Koulali into a general hospital to be administrated by Mary Stanley and her party. ${ }^{20}$ Mary Stanley took charge of the Koulali 


\section{Texts and Documents}

installation on 24 January (the day after her letter to Mrs. Gladstone) on a quasiindependent basis, but was soon overwhelmed by the task and on 31 January complained to Sidney Herbert that she was exhausted and could not obtain succour from Florence Nightingale and requested additional nurses from Britain. ${ }^{21}$ The fault lay with Mary Stanley who failed to maintain discipline among her charges, permitted Mother Bridgeman to flagrantly proselytize among the patients, and refused to recognize the overall jurisdiction of either Florence Nightingale or Dr. Cumming. ${ }^{22}$

While requesting Herbert to accede to Mary Stanley's request, Florence Nightingale countered Stanley's complaints by candidly informing Herbert that no amount of assistance would enable Mary Stanley's 'Koulali plan'- 'a spiritual flirtation between the ladies and the soldiers'-of hospital management to work. ${ }^{23}$ And, indeed, Mary Stanley's reign at Koulali was brief. She had depended upon the British Ambassador's wife, Lady Stratford de Redcliffe, to provision the Koulali hospital, but got little except sympathy. Now, as the hospital wallowed in filth, the death rate among patients soared, and Florence Nightingale continued to spurn her pleas for aid, Mary Stanley became desperate and sought to extricate herself from her dilemma by making good her persistent threat to return home. ${ }^{24}$ She returned to Britain in May 1855, and left no working hospital organization behind her at Koulali. ${ }^{25}$

Despite the defence of Mary Stanley's conduct and the criticisms of Florence Nightingale's treatment of Mary Stanley and her party by Lord Stanmore and by such members of the Stanley group as Elizabeth Davis, Sister Mary Aloysius Doyle, and Fanny Margaret Taylor, ${ }^{26}$ most biographers of Florence Nightingale charge Mary Stanley with having undermined Miss Nightingale's authority and 'injured if . . . not wrecked ... [her] ... scheme of getting military nursing started on lines that were right all through ... ${ }^{27}$ They also declare that before and after her return to Britain Mary Stanley supported intrigues and spread false rumours against Florence Nightingale. ${ }^{28}$ However, Sir Edward Cook, in his account of the 'unfortunate dispute', deprecated the 'needless asperity' which marked Lord Stanmore's view of Florence Nightingale's conduct and stated that 'Miss Nightingale's resentment was perfectly justified . . . ', but also deplored 'Her handling of the crisis . . . [as] unfortunate.' Although Mary Stanley did not administer the nursing services 'altogether according to Miss Nightingale's ideas ...,', wrote Cook, she sincerely attempted to render aid 'to the afflicted'. ${ }^{29}$

Mrs. Battiscombe is convinced that there was little to be said for Mary Stanley's scheme to share the glory attaching to her old friend and to intrude Roman Catholic influence in the British nursing effort at Constantinople and cites a few passages from 'a long and most disingenuous letter' to Mrs. Gladstone to show how Mary Stanley sought to discredit Florence Nightingale and win support for her cause. ${ }^{30}$ Fortunately, asserts Mrs. Battiscombe, Mrs. Gladstone soon heard the other side of the quarrel and quickly disentangled herself from the bitter and long-standing Stanley-Nightingale controversy. 'It is to be hoped', Mrs. Battiscombe concluded, 'that Florence Nightingale forgave Catherine [Gladstone] for her innocent participation in Mary Stanley's scheme and that she accepted as a peace-offering the kindly present of a warm dressing gown that Catherine... delivered to her'. ${ }^{31}$

The following documents from the Glynne-Gladstone manuscripts provide the full 


\section{Texts and Documents}

text of Mary Stanley's long letter of 23 January 1855 to Mrs. Gladstone, and the surviving fragment of Florence Nightingale's very cool response to Mrs. Gladstone's attempt to make amends for her role in the Stanley-Nightingale conflict. ${ }^{32}$

Embassy, Pera

Jan 23 [1855]

My dear Mrs. Gladstone,

I have had such a press of work I have never been able as I wished to write to you again.

I have written at great length to Mrs. Herbert"s today as to the state of things here. I am so afraid they may not understand it, or be vexed with me. All I hope is that Mrs. H. will remember that I came out loving Florence [Nightingale] as much as she did and that I was long and loth to believe she was not as great as I believed her to be.

If you knew what it was to me to hear every one complaining of her and to feel that the blessing given by the nurses is so immense, and that so few comparatively enjoy it. Miss Emily Anderson has been for a fortnight at the General Hospital, s4 but she has sent in her resignation for she felt she could not work with Florence.

Miss Tebbutt ${ }^{25}$ has I believe written to you. She, I think, will wish to go home, she is so miserable. The hardships are so useless, for it would be a half drop in the ocean that would make them comfortable and they feel that the work they are allowed to do is so very small compared with what might be done, or what they could do at home. The Irish nurses feel this especially. ${ }^{38}$

I am very glad the news here is now absorbed so that the public at large will not see the mistake made and France will not see us travelling back rejected.

I am going to settle in at Koulali. I am to have Miss Anderson and Miss Tebbutt with me-unless she goes home-and I earnestly hope I may find that Miss Anderson will be able after a time to take my place so as to allow me to come home.

I long to do so and nothing keeps me here but a strong sense of duty and a wish to help my friends in this emergency and my country. Nothing can exceed Lady Stratford's affectionate kindness to me and can only be appreciated by those who know this place and the difficulty of moving about.. ${ }^{27}$ Going over to Scutari from the Embassy is a regular business. First in a Sedan Chair, or walking, down to the Golden Horn - then in a boat across the Bosphorous-which is constantly too rough to be crossed at all-and then up a steep hill at Scutari.

All I have hitherto seen of what she (Lady S) has done is admirable and what the wife of the English Ambassador in the present crisis ought to do. I never knew her before and therefore can only speak as to what I see now. I grieve to see that Florence considers her exertions as interfering and that what ought to be such support and assistance is cast away. ${ }^{88} \mathrm{I}$ have just been reading The Times account of the Hospitals and am much struck with the truth of the statements as to the real use of the women sent out-not as nurses-but as purveyors in the wide sense of the word. ${ }^{30}$ I feel it would save so much trouble and discussion if Florence would have stated this more clearly.

My position here is a wretched one, for I do not know who to trust. It seems so heartless to act against the friend of many years, in concert with a new acquaintance of power and authority, but what can I do. My whole judgement is against Florence's view. For a long time I hoped to be convinced she was right, but that hope is now over.

I was so disturbed at first by the hard view she took of the Herberts-coming fresh as I did from them and their untiring efforts to serve her and the cause.40 This made me feel we were on different lines, for the error was in their over anxiety to do good and assist her.

I write all this to you dear Mrs. Gladstone to relieve myself. If I have told you more of the case than you knew before, do not betray me.

I am sure if you are in London you will go to my dear mother"1 and talk to her-she feels, she says, such a weight of anxiety, which she keeps to herself about all this, and you may be able to tell her more of Lady Stratford's dependableness or not than I know. 


\section{Texts and Documents}

It is such miserable double dealing here. Each party pressing to know what the other says of them-which I cannot tell either.

How often I have longed for Mrs. Monsell, ${ }^{2}$ or one like her. I longed to stay at Therapia in charge of the [General] Hospital there, though the Chaplain did preach at Miss Tebbutt for lending the Christian Year. ${ }^{48}$

Among the sick, I one day found a man (John Moore) who was a native of Chester and had relations at Hawarden. He told me a story of a wicked uncle 'Tommy Davies' who lived up on Buckley mountain ${ }^{44}$ and who had alienated his father's money by going to the house and finding his brother-in-law dead, he signed a will with the dead hand.

It was so long since Moore had been at Hawarden that he knew little of the present state.

Will you tell Mrs. Talbot that her present to Miss Tebbutt has been quite invaluablethe hot water bottle. Often and often have I had the benefit of it and it has been such a comfort.

Miss Emily Anderson, I fear does better as 2nd rather than 1st [nurse]. She is not clear or decided enough to command. I am very glad to have her with me at Koulali and I hope I may be able to send a brighter account of ourselves before long.

It is heart sickening to hear the accounts of those who came down from the Crimea. In vain I ask is there no counter statement. The answer always is-none.

It seems impossible to exaggerate the misery of our troops. The blight that seems to come over every attempt to assist them. Dr. Cumming, ${ }^{45}$ the Inspector General of Hospitals, came down yesterday. He is a cold hard man, but even he was roused to warm expressions by all he had seen. ${ }^{46}$

About the 8 nurses going. ${ }^{47}$ I have sent my mother the requisition for them, as an answer to all who will exclaim over the madness of such a step. They were willing and anxious to go. They are all women able to take care of themselves and Miss $\mathbf{N}$. did not feel justified in saying they should not go.

I must not write any more dear Mrs. Gladstone. How rejoiced I shall be to see you again. I trust I may soon be released from this place.

My kindest regards to Mr. Gladstone.

Ever yours very affectionately

M. Stanley

Do write to me and direct your letter to me, British Embassy, Pera.

... My own effigies and praises which you sent me by the last mail were less welcome. I do not affect indifference towards real sympathy, but I have felt painfully, the more painfully since I have had time to hear of it, the éclat which has been given to this adventure of mine, on Every day one in another Church. The small, still beginning, the simple hardship, the silent and gradual struggle upwards, these are the Climate in which an Enterprise really thrives and grows. Time has not altered our Saviour's Lesson on that point which has been learnt successively by all reformers from their own experience.

The vanity and frivolity which the éclat thrown upon this affair has called forth has done us unmitigated harm and mischief on perhaps the most promising enterprise that ever set sail from England. Our own old party which began its work in hardship, toil, struggle and obscurity has done better than any other and I, like a Tory, am now trying to get back to all my old regulations.

Yours, whatever betide F.N.

Scutari. July, 1855.

\section{REFERENCES}

1. Battiscombe, Georgina, Mrs. Gladstone. The Portrait of a Marriage, London, 1956, p. 103. 


\section{Texts and Documents}

2. On the life and career of Mary Stanley (1813-79) and her conflict with Florence Nightingale, see Nancy Mitford, ed., The Ladies of Alderley being the Letters between Maria Josepha, Lady Stanley of Alderley and her Daughter-in-Law Henrietta Stanley during the Years 1841-1850, London, 1950, pp. 5, 10, 18ff, 129, 241, 271ff, 297; Nancy Mitford, ed., The Stanleys of Alderley. Their Letters between the Years, 1851-1865, London, 1968, pp. xvi-xviii, 42, 92ff, 134-35; Rowland E. Prothero, The Life and Correspondence of Arthur Penrhyn Stanley, D.D., Late Dean of Westminster, London, 1893, vol. 1, pp. 445, 490-93; Dean Stanley's memoir of his sister in Arthur Penrhyn Stanley, Memoirs of Edward and Catherine Stanley, London, 1880, pp. 33347; Cecil Woodham-Smith, Florence Nightingale, 1820-1910, London, 1950, pp. 69, 71, 98, 145, 181-95; Sir Edward Cook, The Life of Florence Nightingale, London, 1913, vol. 1, pp. 166, 188-93; I. B. O'Malley, Florence Nightingale, 1820-1856. A Study of Her Life down to the End of the Crimean War, London, 1931, pp. 135, 197, 221, 243, 252-92; Lord Stanmore, Sidney Herbert. Lord Herbert of Lea. A Memoir, London, 1906, vol. 1, pp. 355-56, 371-79; M. S. [Mary Stanley], 'Ten days in the Crimea', Macmillan's Magazine, February 1862, 5, 301-11; Mary Stanley, True to Life: A Simple Story, London, 1873.

3. Mitford, The Stanleys of Alderley, pp. xvi, 42, 96, $134-45$.

4. Woodham-Smith, op. cit., p. 145; Cook, op. cit., vol. 1, p. 443; see also [Mary Stanley], Hospitals and Sisterhoods, London, 1954.

5. O'Malley, op. cit., p. 135; Woodham-Smith, op. cit., p. 183.

6. O'Malley, op. cit., pp. 221, 251-52; Woodham-Smith, op. cit., p. 183; Maria Josepha Stanley to Lady Stanley, 26 March 1852, Mitford, The Stanleys of Alderley, p. 93.

7. M. J. Stanley to Lady Stanley, 30 November 1854, Mitford, The Stanleys of Alderley, p. 95.

8. Woodham-Smith, op. cit., p. 181; O'Malley, op. cit., p. 252; see also Jane Williams (ed.), The Autobiography of Elizabeth Davis. A Balaclava Nurse, London, 1857, vol. 2, pp. 94-5.

9. Stanmore, op. cit., vol. 1, pp. 370-72; Cook, op. cit., vol. 1, pp. 188-89; O’Malley, op. cit., p. 253.

10. Cook, op. cit., vol. 1, pp. 190-191; Woodham-Smith, op. cit., pp. 181-82, 186.

11. O'Malley, op. cit., p. 256; Woodham-Smith, op. cit., pp. 184-85.

12. Strachey, LYTton, Eminent Victorians. Cardinal Manning-Florence NightingaleDr. Arnold-General Gordon, London, 1918, p. 137; Stanmore, op. cit., vol. 1, p. 404.

13. O'Malley, op. cit., pp. 256-57; Woodham-Smith, op. cit., p. 186; Stanmore, op. cit., vol. 1, pp. 373, 377.

14. O'Malley, op. cit., p. 258; Woodham-Smith, op. cit., pp. 186-87.

15. Stanmore, op. cit., vol. 1, p. 375; Woodham-Smith, op. cit., p. 188.

16. Woodham-Smith, op. cit., pp. 188-89; O’Malley, op. cit., p. 262.

17. Woodham-Smith, op. cit., pp. 189-90.

18. Woodham-Smith, op. cit., pp. 190-91; see The Times, 9 January 1855.

19. O'Malley, op. cit., p. 265; Woodham-Smith, op. cit., p. 191.

20. O'Malley, op. cit., p. 274; Woodham-Smith, op. cit., p. 192.

21. O'Malley, op. cit., pp. 274, 291, Woodham-Smith, op. cit., pp. 194-95.

22. Woodham-Smith, op. cit., p. 193; O'Malley, op. cit., p. 288.

23. O'Malley, op. cit., pp. 290-91; Woodham-Smith, op. cit., p. 194.

24. Woodham-Smith, op. cit., pp. 193-94; O’Malley, op. cit., pp. 291-92.

25. Stanmore, op. cit., vol. 1, p. 379; O'Malley, op. cit., p. 292.

26. Williams, Autobiography of Elizabeth Davis, vol. 2, pp. $90-92 \mathrm{ff}, 107 \mathrm{ff}, 126-27,152 \mathrm{ff}$;

Sister Mary Aloysius Doyle, Memories of the Crimea, London, 1904, p. 17, 22ff, 35ff;

Fanny Margaret Taylor, Eastern Hospitals and English Nurses-The Narrative of Twelve Months Experience in the Hospitals of Koulali and Scutari by a Lady Volunteer, London, 1957.

27. Woodham-Smith, op. cit., pp. 184, 195; O'Malley, op. cit., p. 293. 


\section{Texts and Documents}

28. O'Malley, op. cit., pp. 326-27, 367; Woodham-Smith, op. cit., pp. 227, 245.

29. Cook, op. cit., vol. 1, pp. 189n, 193.

30. Battiscombe, op. cit., pp. 104-5.

31. Ibid., p. 105.

32. Mrs. Gladstone's correspondence in the Glynne-Gladstone MSS., St. Dieniol's Library, Hawarden, Flintshire (courtesy of Sir William Gladstone and the Warden of St. Dieniol's Library, the Rev. Dr. J. S. Lawton).

33. Mrs. Mary Elizabeth A'Court Herbert (1822-1911), mother of seven children.

34. Miss Emily Anderson was one of the nine 'ladies' in Mary Stanley's party. (Williams, Autobiography of Elizabeth Davis, vol. 2, p. 94). On 24 December Mary Stanley wrote to Mrs. Herbert that she was considering Florence Nightingale's suggestion that she take charge of the General Hospital in Scutari and that if she decided to do so she would 'put Miss Emily Anderson in the way of carrying it on . . . Before Mary Stanley was installed at the hospital in Koulali, Miss Anderson and part of the Stanley group took charge of the General Hospital and, according to Mary Stanley, found her work 'painfully interesting'. See Stanmore, op. cit., vol. 1, pp. 375, 406; O'Malley, op. cit., p. 265.

35. Miss Tebbutt was also one of the 'ladies' in the Stanley group and, like Miss Anderson, one of the most able members of the Stanley party. After Mary Stanley's departure, Miss Tebbutt became Superintendent at the General Hospital. (Williams, Autobiography of Elizabeth Davis, vol. 2, p. 94; O'Malley, op. cit., p. 358; WoodhamSmith, op. cit., p. 191.)

36. The fifteen nuns were Irish Sisters of Mercy under the authority of the very difficult Mother Frances Bridgeman of Kinsale. She pressed hard to get all the nuns into the Scutari hospital, but it was finally arranged for five nuns to work at the General Hospital in Scutari while the remaining ten (including Mother Bridgeman) stayed with Mary Stanley at Koulali. Florence Nightingale was convinced that these nuns were more interested in converting patients to Roman Catholicism than in nursing. (Woodham-Smith, op. cit., p. 193; O'Malley, op. cit., pp. 252, 265, 288; Williams, Autobiography of Elizabeth Davis, vol, 2, p. 94.)

37. Eliza Charlotte Alexander (d. 1882), Lady Stratford de Redcliffe, was the second wife of Stratford Canning, first Viscount Stratford de Redcliffe, British ambassador in Constantinople (1841-46 and 1848-58). Although Lord and Lady Stratford were extremely kind to Mary Stanley, they did not provide funds to replenish the money she lacked to sustain her group. One of the Stanley nurses, Elizabeth Davis, recalled that the Stratfords were always ready to befriend the casualties and to help the ladies and nurses in the Stanley party and merited the great respect of all. In March 1855, Lady Stratford berated the Head Chaplain at the General Hospital for wrongly accusing Mary Stanley of Romanist propaganda and for abetting Florence Nightingale's 'jealousy' of Mary Stanley. After Mary Stanley's departure, Lady Stratford submitted a bill for $£ 8,000$ to the Government for purveying the Koulali hospital. See Williams, Autobiography of Elizabeth Davis, vol. 2, pp. 152, 165-66; Woodham-Smith, op. cit., pp. 186-87, 195.

38. Woodham-Smith asserts that Florence Nightingale never got much help from Lady Stratford and even less from Lord Stratford. Yet, Lady Stratford treated Florence Nightingale as 'a member of her class' and for a time acted as an authorized intermediary between Lord Stratford and the hospital authorities. (Woodham-Smith, op. cit., pp. 175-77; O'Malley, op. cit., p. 243.) On the other hand, J. H. Skene, in his recollections of service with Stratford during the Crimean War, praised Florence Nightingale's work and averred that the ambassador greatly appreciated her service. (James Henry Skene, With Lord Stratford in the Crimean War, London, 1883, pp. 37-39.)

39. See article on military hospitals and the 'overplus' of nurses in the theatre of war in The Times, 8 January 1855. 


\section{Texts and Documents}

40. Lord Stanmore wrote that 'The only crumb of comfort' which accompanied Florence Nightingale's 'terrible letters' to Herbert was a brief note from Mary Stanley to Mrs. Herbert during the second week of January lauding Sidney Herbert for a job well done. 'I wished just to give you a hopeful word', she wrote, 'and believe that I act impartially and fairly. I am sure what has weighed most upon me here has been the thought of all the trouble to you ...' (Stanmore, op. cit., vol. 1, p. 397).

41. Catherine Leycester Stanley (1792-1862), wife of Edward Stanley (1779-1849), Bishop of Norwich.

42. Mrs. Monsell, the Superior of an Anglican order of nuns, was a friend of Mary Stanley. Mrs. Battiscombe remarked that Mrs. Monsell would 'seem to be the very last person whose presence would have commended itself to Mary Stanley . . . ' because Mary Stanley had deliberately organized her nursing party "with the definite though secret intention of enabling the Roman Catholic Church to share in the glory attaching to ... Florence Nightingale . . . . (Battiscombe, op. cit., pp. 104-5.)

43. The Evangelicals at the General Hospital in Scutari accused Miss Tebbutt of 'circulating improper books in the wards' and specifically of lending a copy of the Puseyite publication, The Christian Year (John Keble, Christian Year: Thoughts in Verse for the Sundays and Holy Days throughout the Year, 38th ed., London, 1850) to a patient. On 5 January 1855, Mary Stanley reported to Sidney Herbert: 'Mr. B. [the Chaplain] complained yesterday to Miss Jebbutt [sic] that very improper books had been circulated in the wards; she pressed in vain to know what they were. As I was coming away he begged for five minutes' conversation, and said . . . he must protest against sentiments he neither approved nor understood, and that he would fetch me the book. It was Keble's 'Christian Year', which Miss Jebbut had lent to a sick midshipman ...' (Stanmore, vol. 1, 381n). The misspelling of Miss Tebbutt's name is undoubtedly the error of Lord Stanmore. See also Woodham-Smith, op. cit., p. 190. After Mary Stanley's death in 1879, her brother, the Dean of Westminster, defended her against the charges that her work at Constantinople was marked by a sectarian bias and was especially incensed 'by the action of the Chaplain . . . who [had] . . . informed Mary that he disapproved of one of her ladies leaving the Christian Year with a sick midshipman ... [and] . . . In consequence ... preached against them the next Sunday, in their presence, as "creeping in unawares, etc."'. (Prothero, The Life and Correspondence of Arthur Penrhyn Stanley, vol. 1, p. 492).

44. Buckley Mountain, a common on the border of Mold and Hawarden parishes, is approximately two miles west-south-west of Hawarden, Flintshire.

45. Dr. Alexander Cumming, Inspector General of Hospitals, was the official to whom Mary Stanley and her group were directed to report. He was present at Mary Stanley's first meeting with Florence Nightingale and informed Mary Stanley that he could not provide for her group out of public funds. Nevertheless, in early January, Cumming was persuaded to absorb the Stanley party by increasing the number of female nurses to fifty. (O'Malley, op. cit., pp. 256, 258; Woodham-Smith, op. cit., pp. 186-87, 191).

46. On the contrary, when Cumming visited the hospital at Koulali he rendered an unfavourable report and rejected Mary Stanley's request to import additional nurses from Britain. (O'Malley, op. cit., p. 289; Woodham-Smith, op. cit., p. 194.)

47. This was apparently a reference to the dispatch, in response to Lord Raglan's request during late January, of eleven nurses to the General Hospital at Balaclava. Although Florence Nightingale did not favour the nurses going to the Crimea, a group of nurses led by Elizabeth Davis of the Stanley party was determined to escape Florence Nightingale's discipline and finally secured her assent for eleven nurses to go to Balaclava. (Williams, Autobiography of Elizabeth Davis, vol. 2, pp. 114-7; WoodhamSmith, op. cit., pp. 192-93.) 